\title{
Manufacturing the Image of Doha: From the Public Face of Architecture to the Printed Media
}

Article in Open House International · December 2013

CITATIONS

2
READS

12

1 author:

Ashraf M. Salama

University of Strathclyde

99 PUBLICATIONS 252 CITATIONS

SEE PROFILE 


\title{
14. MANUFACTURING THE IMAGE OF DOHA: FROM THE PUBLIC FACE OF ARCHITECTURE TO THE PRINTED MEDIA
}

\section{Ashraf M. Salama}

\begin{abstract}
This paper explores image-making efforts in the city of Doha. A multi-layered critical discussion is employed and articulated in a number of procedures that include conceptualizing theoretical underpinnings for understanding image making in terms of contextual and critical approaches, identifying the types of efforts that took place and that are currently taking place towards image making, mapping the contextual and critical approaches on actual examples from the city, and examining the printed media by conducting a content analysis study of two widely acknowledged magazines in an attempt to answer the question of how the country wants to portray its capital city through image-making to the global community. The results of this exploration convey a commitment toward image making, presenting an image of Doha as an emerging international hub. The paper concludes by arguing for the need of critical consciousness in response to that fact that image making practices in Doha continue to subdue the profession to client aspirations through oversimplified imaging while ignoring the professional discourse that scrutinizes the quality of those images and the meanings they convey.
\end{abstract}

Keywords: Doha, Image Making, Globalization, Architectural Identity, Printed Media.

\section{INTRODUCTION}

The interest in creating meaningful places within the professional and academic communities always result in a wide spectrum of approaches to place and image making. Architects and urban designers with interest in incorporating meaning into place typically manipulate different elements to emphasize a locality or reflect an international tendency. These elements are represented through environmental imagery and formal aesthetics, and by depicting history, craft and cultural traditions, or current global trends. Regions, countries, and cities that have cultural richness and multi-layers of history seem to be passionate with that search. Architecture of capital and major cities in the Gulf region are no exception where architects and designers find themselves dealing with the irony of needing to project a certain image of whom they are designing for while advocating the necessity of speaking to the contemporary global culture.

While scholars in architecture may criticise the concern to place emphasis on discussing building expressions and environmental imageries, the premise adopted in this paper is that since architecture is created for the public then examining its public face is essential to the understanding of the juxtaposition of those expressions and images and the meanings they communicate and signify. Concomitantly, the objective is to attempt to offer a comprehensive understanding of image making practices with the city of Doha as a case study; a city that has undergone significant transformation over the past two decades.

In this paper, a multi-layered critical discussion is employed to involve: a) identifying and conceptualizing theoretical underpinnings for understanding image making in terms of contextual and critical approaches, b) reviewing design practices to identify the types of efforts that took place and that are currently taking place towards image making, c) mapping the contextual and critical approaches on actual examples from the city, and d) examining the printed media by conducting a content analysis study in an attempt to answer the question of the way in which the country portrays its capital city through image-making to the global world. OryxQatar Airways magazine and the Edge Business magazine were selected to explore answers to this question.

\section{IMAGE-MAKING: UNDERPINNING CONCEPTS}

While most architectural and urban design practices are oriented to functional, pragmatic, environ- 
mental, and economic concerns, a number of theorists and practitioners are in a continuous quest for a deeper design discourse that employs discussion of local expressions and contextually-based imagery toward creating place identities (Larice and Macdonald, 2007). The globalized city condition has created a sense of placelessness. As a reaction, evoking a sense of place through image making has become a primary concern in contemporary architectural and urban design practices. With this concern, the aspirations are to show history, to introduce new work and living environments, or to articulate the interest of the public in comfort, entertainment manifested in new lifestyles and work styles. These aspirations are supported and sponsored by government agencies and key economic players in shaping the built environment such as real estate developers and city marketers. The pursuit for realizing these aspirations has - in many cases - culminated into a type of symbolism that is painful to comprehend (Salama, 2005).

The conception of image making and its contribution to the city image has been a subject of discussion by theorists and academics since Lynch's Image of the City (1960). Contemporary literature, however, has expanded beyond the work of Lynch to include other parameters. Conceptually, two approaches can be identified to understand the scope of relevant interests and studies in the field of environmental imagery; the contextual and the critical. However, a third approach is also envisioned to place emphasis on the relationship between the visual qualities of the urban environment and those who perceive and comprehend such qualities. Yet, the analysis here is limited to the first two approaches.

The contextual approach fosters an understanding of place by focusing on the regional, historical, and natural aspects of the city or the region within which it exists. The principal theories and practices of this approach have emerged as a reaction to the dissatisfaction with the universal nature of modernism. Critical regionalism, coined by Frampton and elaborated upon by Tzonis and Lefaivre, is the primary theory of this approach (Frampton, 1985; Tzonis and Lefaivre, 2003). It adopts the principle that the reading of a region's history to extract its essence and utilize it to suit the spirit of the time should be a primary design focus. The theory recognizes the interactional value of climate, culture, religion, and craft in making an image. The manifestations of critical regionalism are typically viewed as a way to show cultural, economic, and political independence. In essence, the approach has resulted in a growing interest in discussing the role of identity creation through visual qualities of buildings and the landscape. Directly and indirectly, architectural discourse in the Middle East and the Gulf region has profoundly related contemporary practices to the discourse on regionalism (Salama, 2005; 2012).

The critical approach involves descriptions that analytically discuss the practice of contemporary image making and the growing culture of fictionalizing and capitalist profit-seeking practice. The writings of Harvey (1989) and Huxtable (1981) and other critics have emphasized the value of authentic representation for contemporary societies. One underlying notion of this approach is the introduction of iconicity. Jencks (2005), introduced 'iconic' as a term to denote buildings that involve the incorporation of important and enduring symbols that stand out of the city. He argues that they must be powerful in the sense that they symbolize a memory or nostalgia of an unusual importance. Practices toward materializing iconicity can be witnessed in contemporary developments worldwide and in the growing interest in developing iconic buildings and urban settings throughout Middle Eastern cities.

\section{CLASSIFICATION OF IMAGE-MAKING PRACTICES}

Contextual and critical approaches were utilised to gain a deeper understanding of evolving imagemaking practices in the contemporary architecture of Doha. An analysis of the identified types of efforts toward image making is outlined in the following breakdown.

\section{Symbolism and the Making of an Image}

The use of symbolism in environmental imagery corroborates the notion that most of the important urban and building actions and artistic interventions in the city of Doha are deliberately intended to evoke a real or imagined memory, recall images from the past, or record a significant event, and thus put a political, artistic, or social moment indelibly on record (Figure 1).

In many development efforts within the city, influential decision-makers and developers are actively promoting, together with building professionals, the increased use of traditional symbols to enhance building images and the urban context within which they exist. The ultimate objective is to establish a contextual architectural and spatial language that speaks to the local residents. By and large, the existence of historical and recognisable symbols can help foster a sense of cultural identity while, at the same time, satisfy an inchoate longing to reinstate the vanished intimacy between a com- 


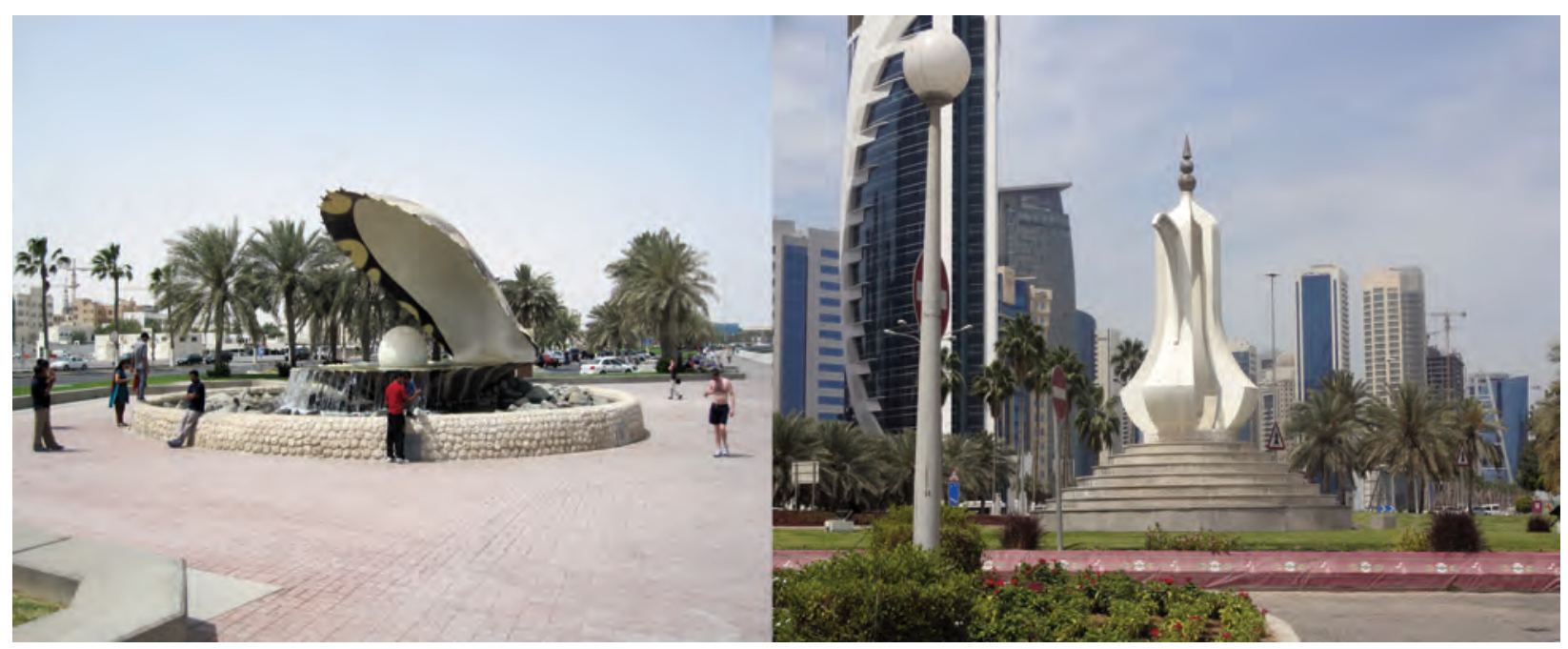

Figure 1. Utilising symbolism in Doha's urban spaces, (left) depicting the vanished pearl industry in a public space in Doha's waterfront, (right) using the 'dallah;' traditional coffee pot-the Gulf Arab symbol of welcome. (Source: Author).

munity and its surrounding physical environment. Indeed, the use of symbols derived from architectural heritage has an important role in invigorating the preservation of traditions and tangible elements of cultural heritage. The desire to instigate a sense of cultural belonging by replicating, through built forms, the visual attributes, signs, and symbols of historical or traditional architecture, has encouraged building professionals to increase the use of such symbols in their contemporary practices with the clear aim of creating iconic buildings or urban settings that establish links with the actual or imagined past. Examples of efforts toward materialising these desires and concepts are evident in a considerable number of buildings and projects in modern day Doha (Figures 2 and 3).

\section{Tradition-modernity dialogue in search for image-identity}

Addressing the sensitive relationship between tradition and modernity is another approach that involves continuous attempts to construct an architectural or urban identity. Tradition, in this respect, can be viewed as both an internal action and a response to external forces and perceived desires. In essence, the result of an interaction between internal influences and external forces helps create an identity. In turn, this understanding contributes to the narrative of expressing cultural identity through architecture and urban form, a narrative, which continues to present and represent itself on the map of architectural practices and urban discourse in Doha. While some theorists see identity as a human need that has transformed itself into a necessity (Correa, 1983; Saliya, 1986), others regard it as a process of constructing meaning on the basis of giving priority to a set of cultural attributes over other sources of meaning (Castells, 2004). Along the same line of thinking, Stewart Hall ((1990) argues, "cultural identity is a matter of 'becoming' as well as of 'being' and that it belongs to the future as much as to the past" (Hall, 1990). Two ostensibly polar qualities are implicit in Hall's

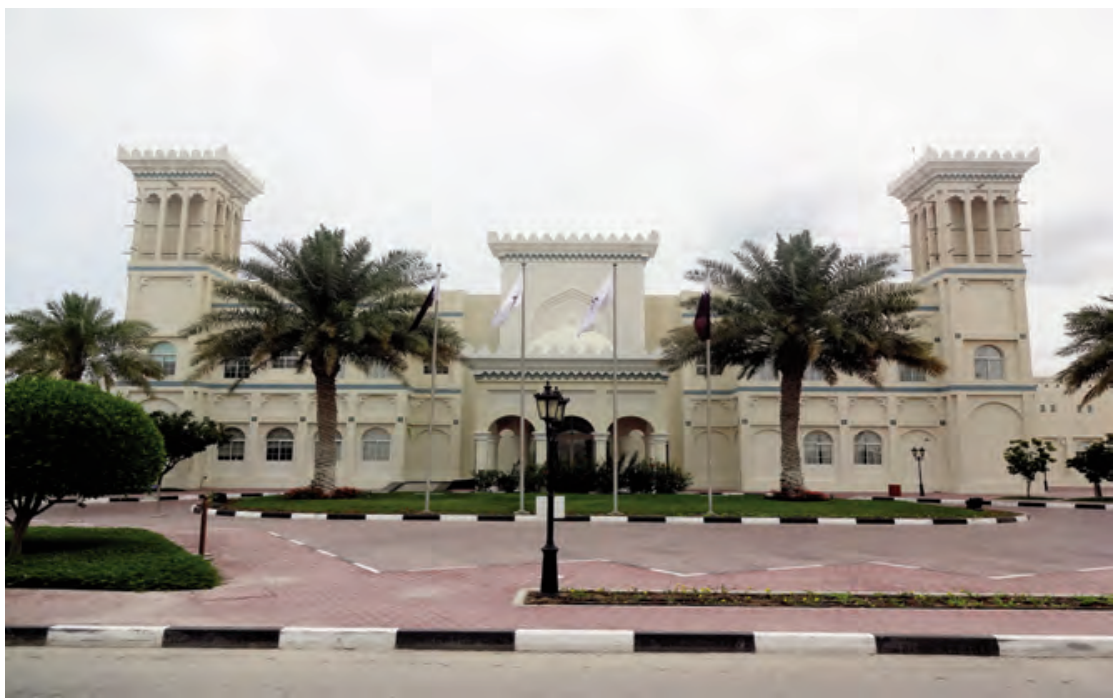

Figure 2. Diplomatic Club of Doha. (Source: Author).. 


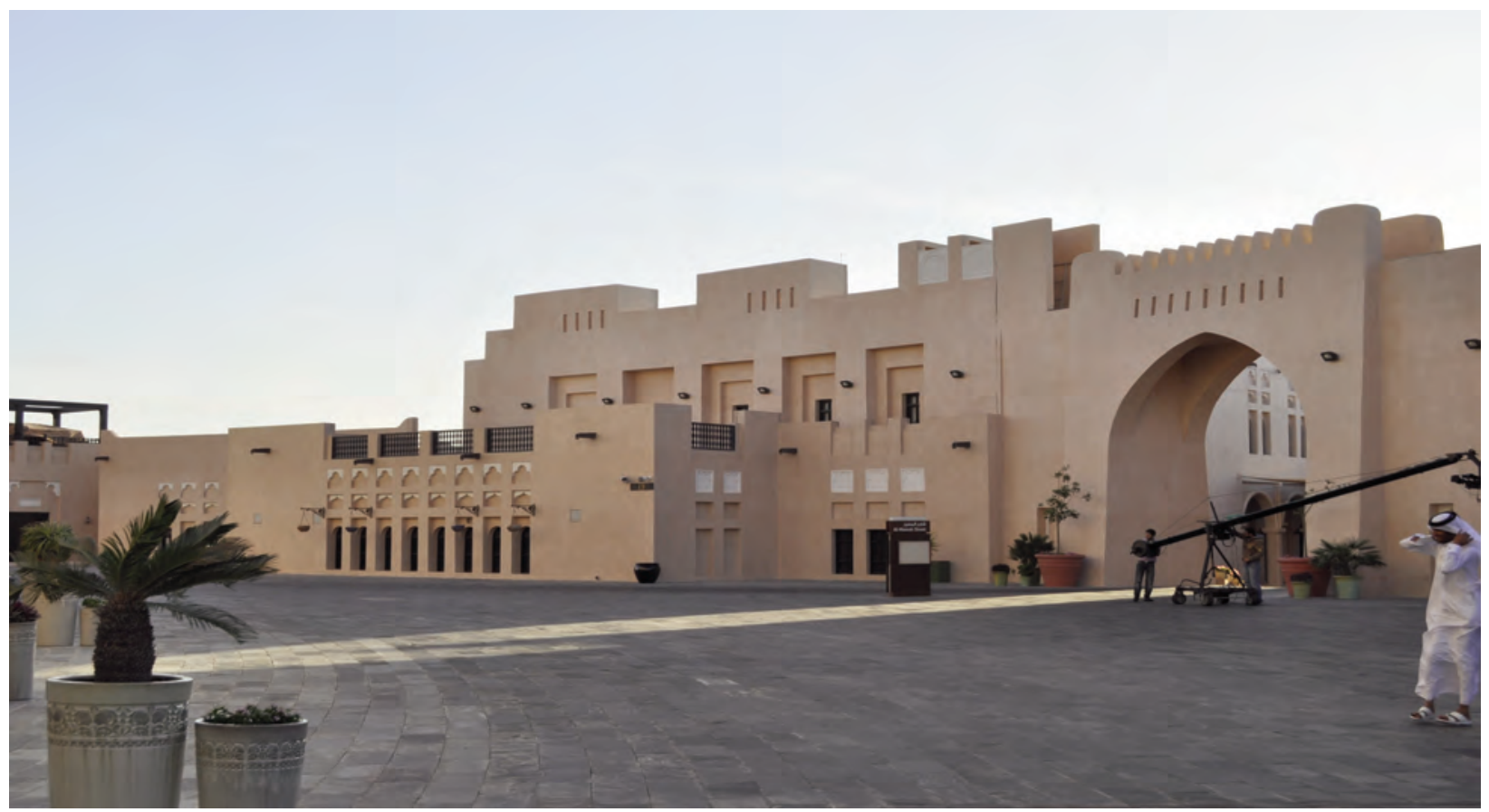

Figure 3. Katara Cultural Village. (Source: Author).

position, reflecting a more in-depth understanding of identity: one relates to similarity and continuity, while the other delineates difference and rupture (Mahgoub, 2007).

Consequently, the idea of identity appears to have three underlying qualities: a) the permanence over time of a subject unaffected by environmental changes below a certain threshold level, b) a notion of unity, which establishes the limits of a subject and enables us to distinguish it from the others, and c) a relationship between two elements, which allows us to recognise them as identical. This suggests that permanence, recognition, and distinction determine the presence of identity in a physical object, a work of architecture, or a portion of a built environment (Salama, 2005; 2012). Indeed, identity can be further understood as the collective aspect of the set of characteristics by which an object, a building, or a portion of the built environment is definitively recognisable.

The city of Doha's earlier efforts at imagemaking can be seen in the buildings of the Qatar University campus, where a visual dialogue was established between traditional design elements and the utilisation of the contemporary technology (Figure 4). As the discourse continues on the dialectic relationships between tradition and modernity, the contemporary and the historic, and the global and the local, a number of important projects exemplify the presence of multiple resistant identi-

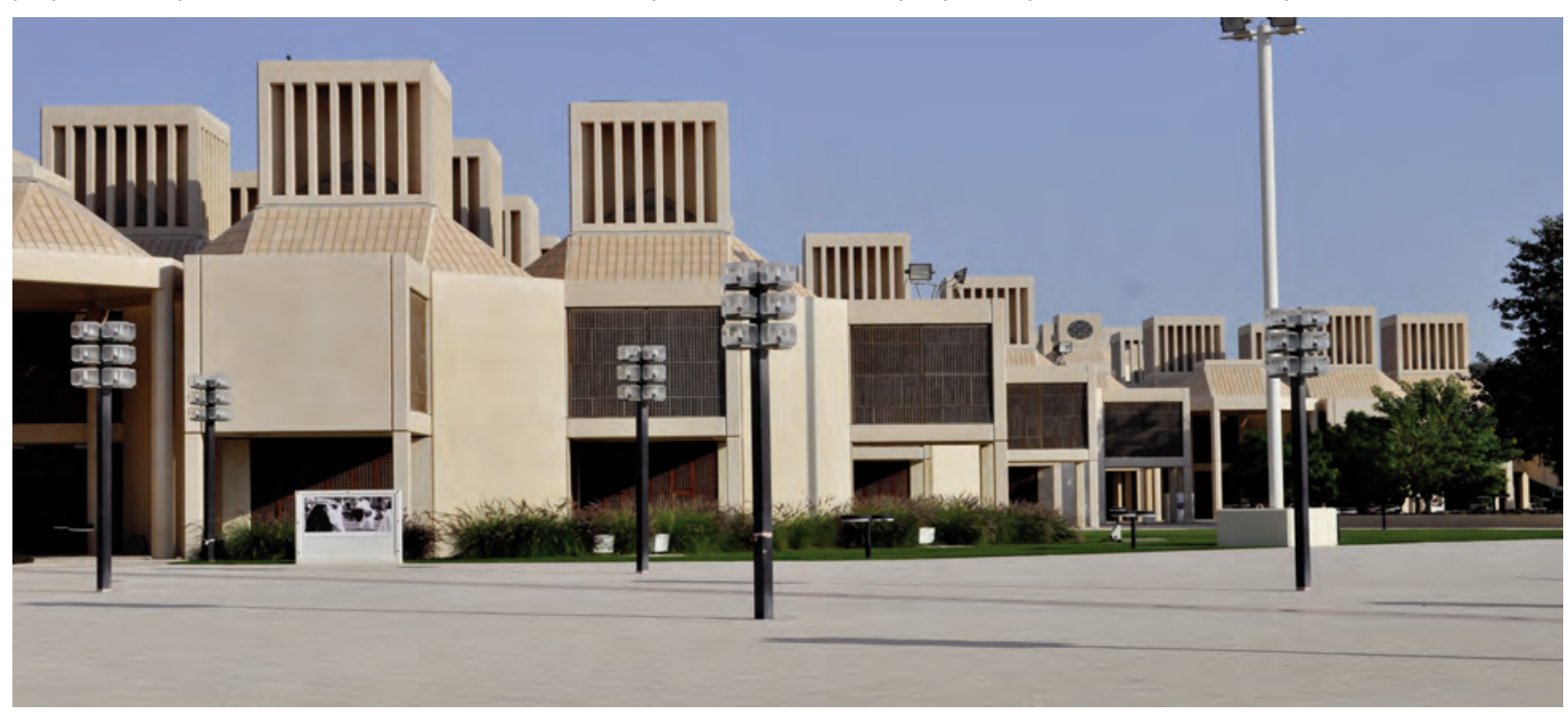

Figure 4. Qatar University Campus; a visual dialogue between traditional design elements and contemporary technology. (Source: Author). 


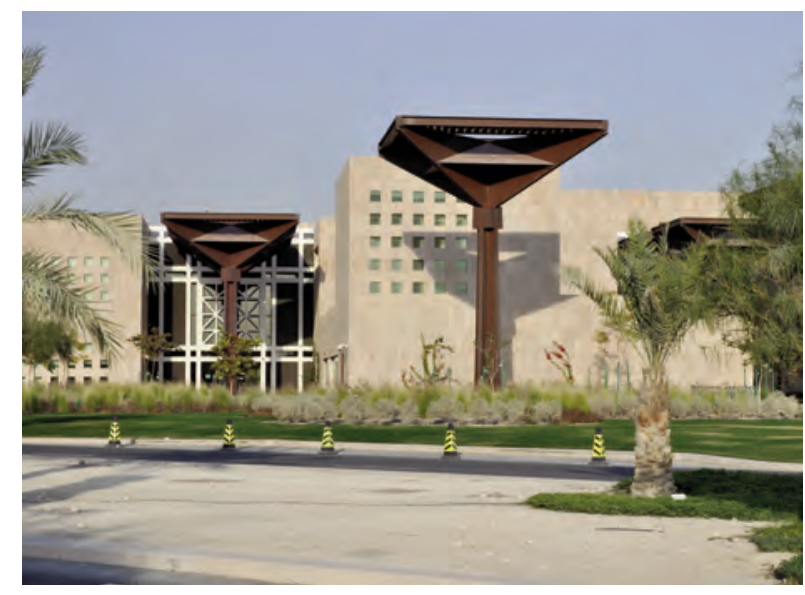

Figure 5. Rooting contemporary architecture of Doha in the application and re-interpretation of regional traditions, the Student Centre of the Education City by Ricardo Legoretta. (Source: Author).

ties. Some architects have continuously attempted to achieve such a balance in their work by developing syntheses of contemporary images based on revived traditions and by simulating traditional environments (Figure 5), in some cases using modern technologies while in other cases combined with traditional techniques. These endeavours aim at returning architecture to its former position of being not only a visual expression of society, but also arising from within it (Salama, 2008; 2012).

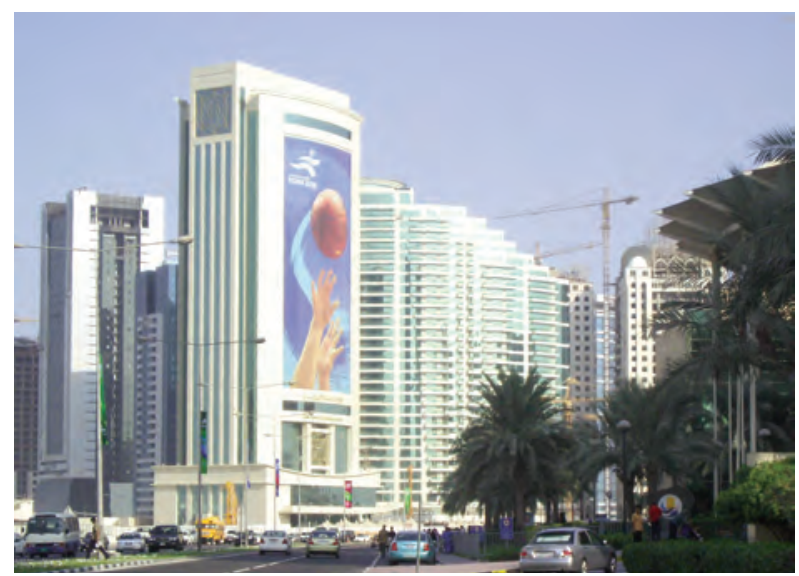

Figure 6. Branding Doha during ASIA-D 2006 Asian

Games through the use of environmental graphics and building wraps. (Source: Author).

\section{Reacting to the Global Condition}

Architecture and urbanism continue to be regarded as a crucial catalyst for cities to sustain their position in the milieu of a global knowledge economy. Reactions to this global condition can be seen in infinite and hybrid urban forms and typologies in Doha. The global condition and its impact on the city and the production of space have been heavily discussed in the literature (Stillerman, 1996). City branding or urban branding is one of the responses to such a situation. As a rising area of discourse, it has emerged as a response to growing global and fiscal competition (Ole, 2005; Synnott, 2010), and as such is witnessed in the realisation of local and regional aspirations with an agenda to entice

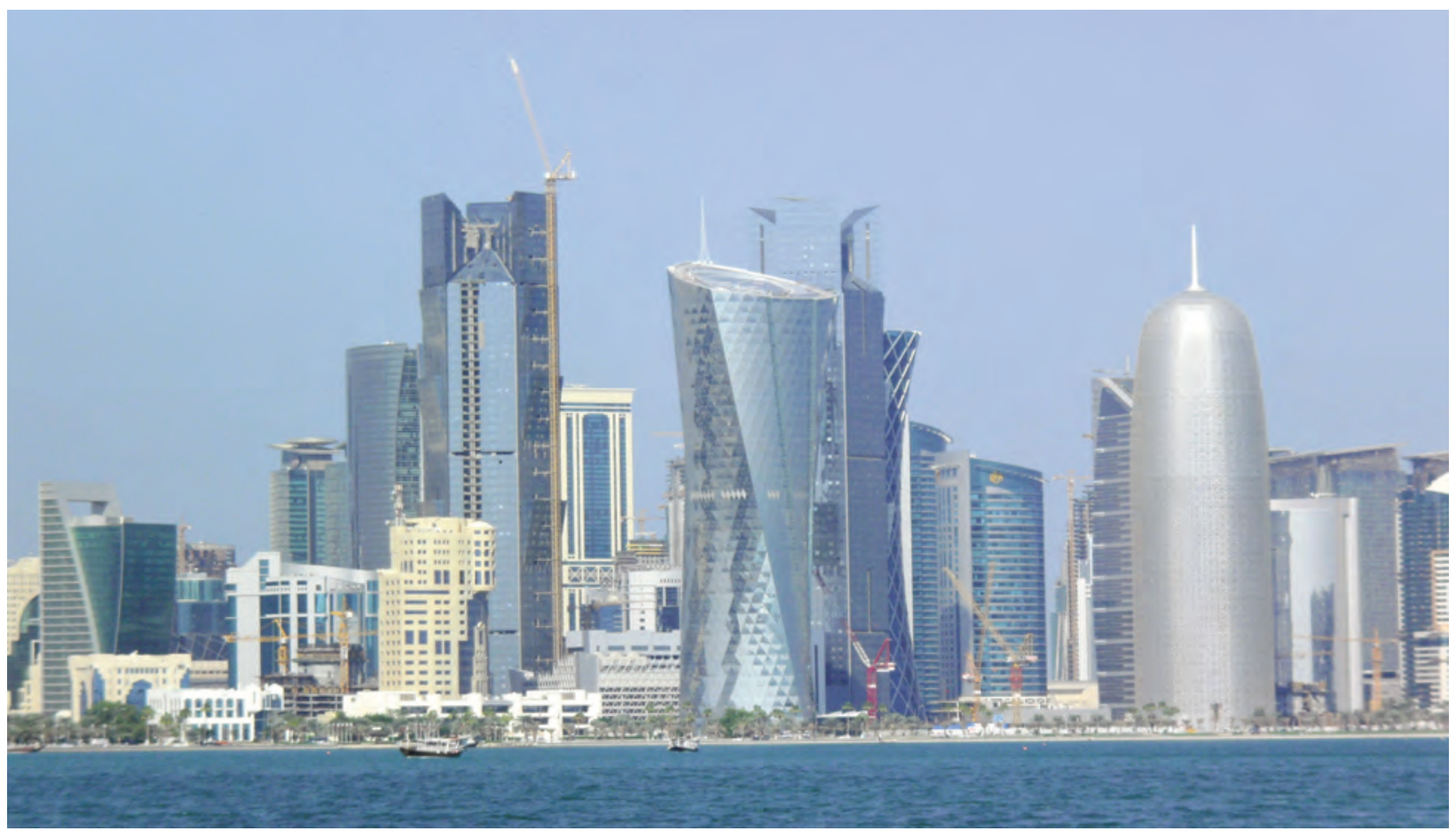

Figure 7. Individual buildings compete to create an iconic urban image that satisfies global aspirations. (Source: Author). 


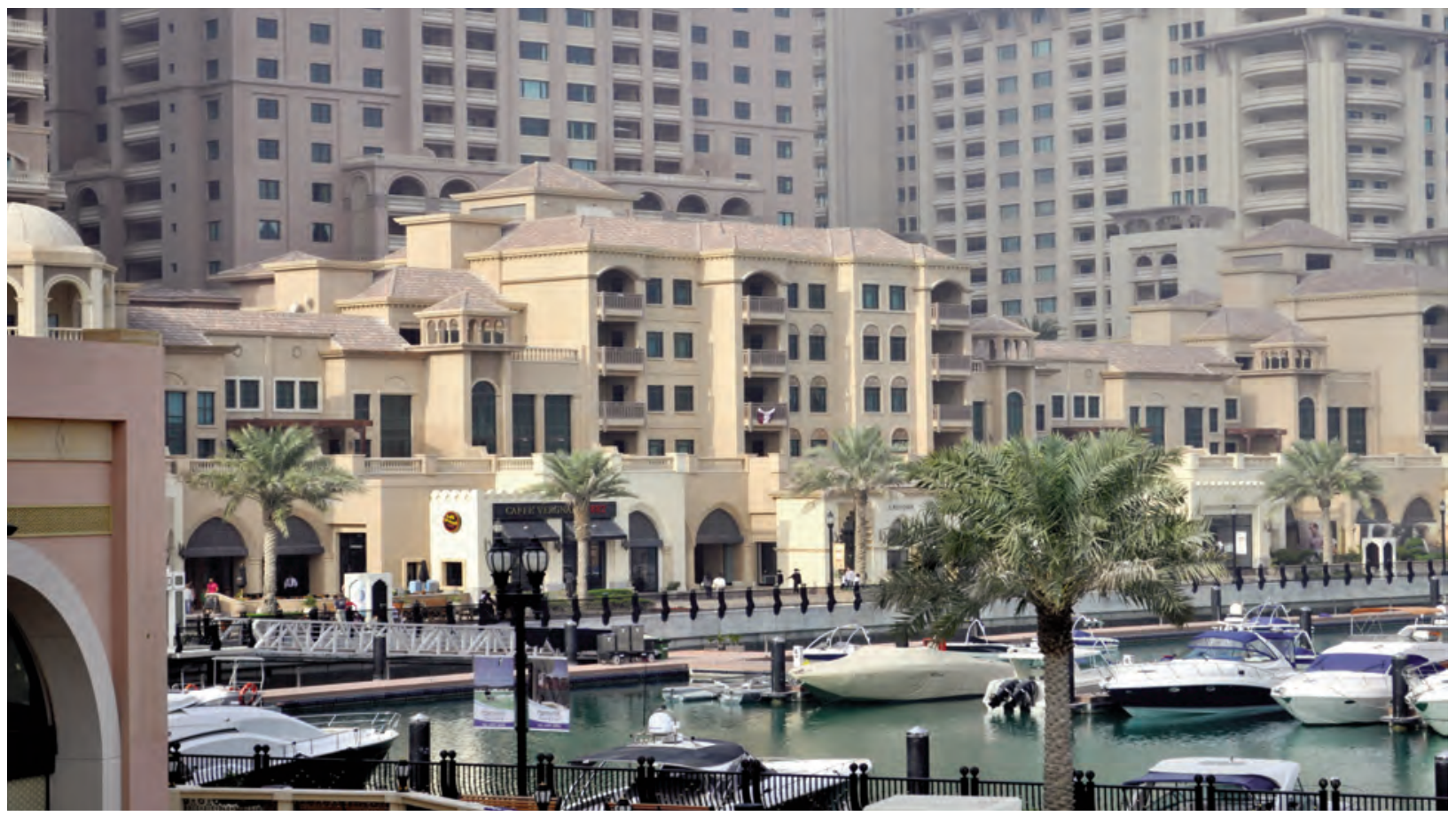

Figure 8. Dominance of the setting over individual buildings; eclectic and hybrid regional styles in the Pearl Qatar development. (Source: Author).

global investment or gain international attention. In this context, two phenomena toward image making can be identified.

The first phenomenon can be seen in the organisation of large-scale stage and hallmark events such as the case of ASIA-D 2006, where the city of Doha branded itself as a sport-based city, a hub for international sporting events, by organising the Asian Games in 2006; this event is considered to be the second largest sporting event in the world after the Olympic games (Hasanin, 2007). Through the use of environmental graphics such as the distribution of strategically placed billboards and signboards throughout the city, sculpture installations in public spaces, as well as building and street wrap pictograms, key areas within the city immediately acquired an instantly recognisable new image (Figure 6). While such an image referent can be considered temporary, pursuing an event of this scale typically results in improving infrastructure, the creation, refurbishing and development of public spaces, and the introduction of new amenities and facilities.

The second phenomenon can be seen in the creation and promotion of urban districts or enclave developments for key segments of society. These types of projects stem from mutually beneficial alliances between government agencies and business interests. By promoting new work opportunities and desirable lifestyles, new urban images are generated in key areas within the city. Examples of this phenomenon are evident in two major development projects. One is Doha's emerging business district, near the waterfront in West Bay, whose visually arresting high-rise buildings have created a strikingly iconic urban image and cityscape (Figure 7). The second project is the exclusive development Pearl Qatar, where various eclectic and hybrid styles of regional and European architecture promote another distinctive development image (Figure 8). While in the first project individual buildings compete aggressively in contributing to the new urban image, priority for image making in the second project is given to the overall urban setting and activities rather than to individual buildings.

\section{PRINTED MEDIA: SPEAKING TO THE GLOBAL WORLD}

Printed media has a significant impact on the impressions the readers develop and the mental images they acquire as a result of their reading. Such an impact is based on a number of factors, namely, the credibility of the media and the way in which their content is presented, understood, and interpreted. In essence, printed media plays a key role in building an image in the minds of readers, especially when targeting specific groups. In answering the question of how Qatar wants to portray itself and its capital Doha to the global community in the printed media, an examination of the influence of printed media was conducted (Salama and Wiedmann, 2013). Two important monthly magazines were selected: Oryx, the official in-flight magazine of Qatar Airways, and Edge magazine 

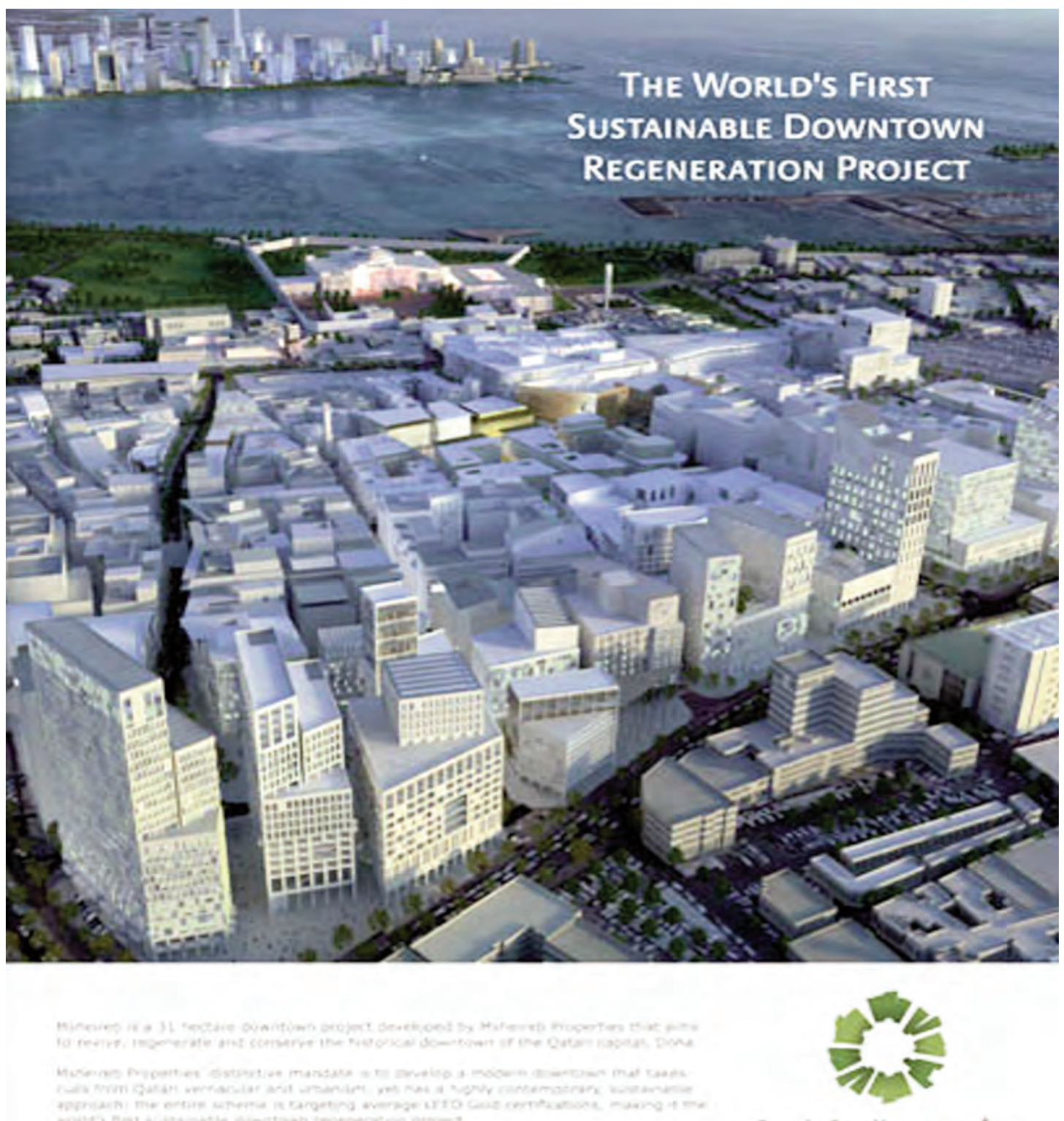

âtlóll נرsiso MSHEIREB PROPEFTIES

Figure 9. An example of Oryx-Inflight magazine of Qatar Airways; promoting sustainable downtown regeneration as a distinctive real estate development project. (Source: Oryx, October 2011 ).

(Figures 9 and 10), which represents itself as Qatar's catalyst for business. Articles and advertisements published over the past three years in the two magazines were examined based on their availability.

A total of thirty-two issues of Oryx magazine published during the period from December 2009 to July 2012 and a total of twenty-seven issues of Edge magazine published during the period from April 2010 to June 2012 were the subject of investigation. In both, articles and advertisements, textual and visual materials were investigated. While articles were scrutinised through the titles, subtitles, banners or slogans used, and the accompanying images, advertisements were surveyed based on their mottos, slogans or captions, and the

- 12 associated images. Emphasis was placed on images related to architecture, building sites, master plans, or general urban scenes from the city: these convey different conceptions and ideas about how the city looks and how it works. Five categories were evaluated: these were business, sports, culture and tourism, education and knowledge, and real estate. Categories related to retail or fashion were excluded. Since both magazines have sections relevant to other contexts or countries, articles and adverts that do not directly relate to Doha and the context of Qatar were also excluded.

The business category includes articles and advertisements that promote Qatar's interest in establishing partnerships in the fields of information technology, oil and gas petrochemical industries, 


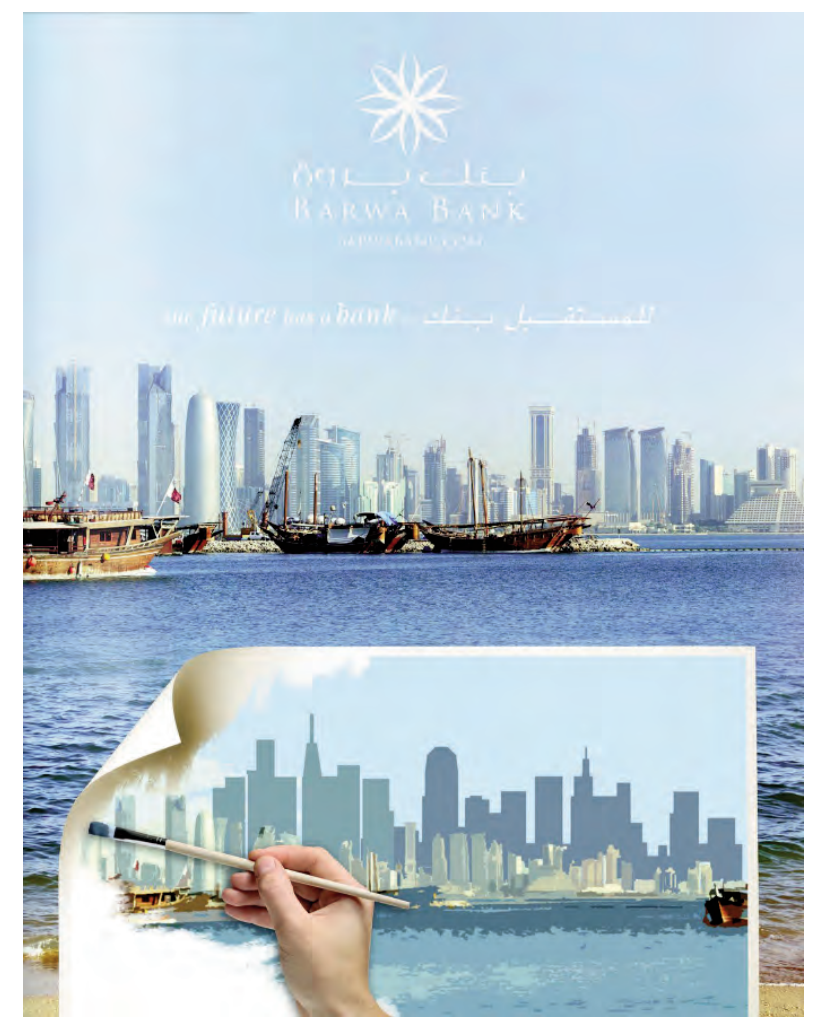

Figure 10. An example of Edge magazine; promoting investment and banking through the image of the West Bay as an emerging business district. (Edge, January 2011).

sustainable technologies, energy production and conservation, and construction industries. Images associated with this category showcase views of factories, advanced industries, industrial plants, banking, or scenes from the business districts.

The category of sports includes materials that represent the role of Doha throughout the past decade in developing its resources to enable it to become key tourist destination and an effective host of regional and international sporting events, championships, and league matches. Images in this category include existing facilities and proposals for new stadiums, while emphasising the technologies and sophistication involved in such structures.

The culture and tourism category has materials that depict the recent role the country has played in investing in cultural projects and museums, promoting conservation of the arts, and the protection of architectural heritage. They represent Qatar as a centre for diverse cultures, a cultural hub that hosts art exhibitions, high profile cultural events, and international concerts and festivals. Images in this category include artwork, existing museum buildings and proposals for new cultural projects.

The fourth category is education and knowledge, which includes materials that showcase Qatar as a centre of excellence in education and research and the role of Doha as an emerging knowledge-based economy city. Images associated with this category include laboratories, conference halls, and educational institutions. The fifth category is real estate; this includes materials that picture Doha as an interesting and liveable environment with many new career options and lifestyles that support business and attract a highly qualified and talented workforce. Images in this category include scenes of recently completed residential projects, projects in progress, or future proposals that exhibit vibrant, upscale work and residential environments.

With regard to both articles and advertisements, it should be noted that a single article could cover more than one of the preceding categories while one advertisement might provide messages or images that could relate to one or more categories. For the articles examined in Oryx magazine, a total of 272 responses to the categories were recorded while 388 responses to the same set of categories were noted in the articles examined in Edge magazine (Table 1). In Oryx, culture and tourism received the highest number of responses with over two-thirds of the total responses (66.00\%), while business was ranked as the second category, receiving $14.33 \%$ of the total responses. The categories of sports and real estate received equal responses and were ranked as the third with 9.19\% of the responses.

A surprising result emerged from the education and knowledge category in that it received the lowest responses (1.1\%) despite the fact that Qatar Foundation, Qatar University, and the Supreme Education Council are making a considerable investment in the architecture of educational facilities, as for example those at Education City, which are designed by name international architects. The results with regard to the articles published in Edge magazine were anticipated: since the magazine's focus is on business, the business category received the highest number of responses (64.94\%), followed by real estate (13.91\%), and culture and tourism (9.2\%). The category of education and knowledge is ranked as fourth (6.18\%) while the sports category received the lowest number of responses (5.92\%).

\begin{tabular}{|c|c|c|c|c|c|c|c|c|c|}
\hline $\begin{array}{l}\text { Oryx } \\
\text { Articles }\end{array}$ & $\begin{array}{l}\text { Dec } 09 \\
\text { Dec } 10\end{array}$ & $\begin{array}{l}\operatorname{dan} 11 \\
\operatorname{Dec} 12\end{array}$ & $\begin{array}{l}\operatorname{Jan} 12 \\
\operatorname{Ju} 112\end{array}$ & Total \% & $\begin{array}{l}\text { Edge } \\
\text { Articles }\end{array}$ & $\begin{array}{l}\text { April 198 } \\
\text { Dec 10 }\end{array}$ & $\begin{array}{l}\tan 11 \\
\operatorname{Dec} 12\end{array}$ & $\begin{array}{l}\operatorname{San} 12 \\
\operatorname{Jan} 12\end{array}$ & Total $\%$ \\
\hline Business & 6 & 22 & 11 & \begin{tabular}{|l|}
399 \\
$1433 x$ \\
\end{tabular} & Business & 79 & 110 & 63 & $\begin{array}{l}(252) \\
64.94 \%\end{array}$ \\
\hline Sports & 20 & 4 & 1 & $\begin{array}{l}\text { (25) } \\
0919 \%\end{array}$ & Sponts & a. & 11 & 6 & $\begin{array}{l}\text { (23) } \\
0592 \%\end{array}$ \\
\hline $\begin{array}{l}\text { Culturel } \\
\text { Tourism }\end{array}$ & 32 & 105 & 43 & $\begin{array}{l}(180) \\
660 \% \\
\end{array}$ & $\begin{array}{l}\text { Cultured } \\
\text { Tourism }\end{array}$ & 13 & $7 \pi$ & 5 & $\begin{array}{l}(35) \\
0902 \%\end{array}$ \\
\hline $\begin{array}{l}\text { Educationl } \\
\text { Knowledge }\end{array}$ & 1 & 1 & 1 & 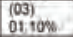 & \begin{tabular}{|l|} 
Education' \\
Knowladge
\end{tabular} & 7 & 11 & $\theta$ & $\begin{array}{l}\text { (24) } \\
06.18 \%\end{array}$ \\
\hline $\begin{array}{l}\text { Real } \\
\text { Estate }\end{array}$ & 6 & 14 & 5 & $\begin{array}{l}25) \\
09.19 \% \\
\end{array}$ & $\begin{array}{l}\text { Real } \\
\text { Estate }\end{array}$ & 18 & 25 & 11 & $\begin{array}{l}\text { (54) } \\
\text { 1391\% }\end{array}$ \\
\hline Total & 66 & 146 & 61 & $\begin{array}{l}(272) \\
100 \%\end{array}$ & Total & 123 & 174 & 91 & $\begin{array}{l}(388) \\
100 \%\end{array}$ \\
\hline
\end{tabular}

Table 1. Results of analysing articles published in Oryx and Edge magazines (Source: Author). 


\begin{tabular}{|c|c|c|c|c|c|c|c|c|c|}
\hline $\begin{array}{l}\text { Oyyx } \\
\text { Adverts }\end{array}$ & $\begin{array}{l}\operatorname{Dec} 09 \\
\operatorname{Dec} 10\end{array}$ & $\begin{array}{l}\operatorname{Jan} 17 \\
\operatorname{Dec} 12 .\end{array}$ & $\begin{array}{l}\operatorname{san} 12 \\
\operatorname{sul} 12\end{array}$ & Total \& & $\begin{array}{l}\text { Edge } \\
\text { Articles }\end{array}$ & $\begin{array}{l}\text { Aprit } 10 \\
\text { Dec } 10\end{array}$ & $\begin{array}{l}\operatorname{dan} 11 \\
\operatorname{Dec} 12\end{array}$ & $\begin{array}{l}\operatorname{Jan} 12 \\
\operatorname{Sun} 12\end{array}$ & Total W \\
\hline \begin{tabular}{|l} 
Business \\
\end{tabular} & 121 & 116 & 55 & $\begin{array}{l}(292) \\
42.19 \%\end{array}$ & Business & 65 & 65 & 24 & $\begin{array}{l}(154) \\
6311 \% \\
631\end{array}$ \\
\hline Sports & 17 & 2 & 2 & $\begin{array}{l}\text { (21) } \\
03.0 \%\end{array}$ & Spots & 5 & 2 & to & $\begin{array}{l}(08) \\
327 \% 6\end{array}$ \\
\hline \begin{tabular}{|l|}
$\begin{array}{c}\text { Culturel } \\
\text { Tourism }\end{array}$ \\
Tourism
\end{tabular} & 56 & 71 & 62 & $\begin{array}{l}\text { 1889) } \\
2731 \%\end{array}$ & $\begin{array}{l}\text { Cultured } \\
\text { Tourism }\end{array}$ & 9 & 5 & 6 & $\begin{array}{l}\text { (20) } \\
8.19 \%\end{array}$ \\
\hline \begin{tabular}{|l|l|} 
Education \\
Knowledge
\end{tabular} & 22 & 20 & 13 & $\begin{array}{l}1555 \\
079466\end{array}$ & $\begin{array}{l}\text { Education } \\
\text { Knowledge }\end{array}$ & 6 & 3 & 00 & $\begin{array}{l}(09) \\
368 \%\end{array}$ \\
\hline \begin{tabular}{|l|}
$\begin{array}{l}\text { Roal } \\
\text { Estato }\end{array}$ \\
\end{tabular} & 60 & 50 & 25 & $\begin{array}{l}(135) \\
19.50 \%\end{array}$ & \begin{tabular}{|l|} 
Real \\
Estate
\end{tabular} & 18 & 24 & 11 & $\begin{array}{l}\text { (53) } \\
21.72 \%\end{array}$ \\
\hline Total & 276 & 259 & 157 & $\begin{array}{l}(692) \\
100 \%\end{array}$ & Total & 104 & 99 & 41 & $\begin{array}{l}(244) \\
100 \%\end{array}$ \\
\hline
\end{tabular}

Table 2. Results of analysing advertisements published in Oryx and Edge magazines (Source: Author).

Advertisements examined in Oryx magazine received a total of 692 responses to five categories while a total of 244 responses were recorded for Edge magazine (Table 2). In Oryx, with regard to advertisements, the category of business received the highest number of responses (42.19\%), while culture and tourism ranked second with $27.31 \%$ of the total responses. This was followed by real estate (19.50\%), education and knowledge (7.94\%), and sports (3.0\%). Comparing these results to the results obtained from analysing the articles, the categories of business and culture and tourism exchange positions in the ranking; however, they occupy the first and second ranks in both articles and advertisements.

The category of education and knowledge ranked fourth, higher in the responses of the advertisements and slightly higher than the same category in articles. The sport category does not appear to be of much interest since it received the lowest number of responses. The results of examining the advertisements published in the Edge magazine were similar to the those of the articles where the business category received the highest responses (63.11\%), followed by real estate (21.72\%), and culture and tourism (8.19\%). Education and knowledge is ranked fourth (3.68\%) while the sports category received the lowest number of responses (3.27\%).

\section{CONCLUSION: TOWARD A CRITICAL CONSCIOUSNESS}

This paper instigated a discussion for exploring image making practices in the city of Doha by identifying two approaches: the contextual, the critical. Within these approaches, interests and types of efforts toward image making were discussed underlying three main tracks. These were: utilizing symbolism in contemporary imaging, manifesting tradition-modernity in search for image identity, and addressing the global condition towards image making. On the other hand, printed media was analysed to explore the way in which the image of the city is portrayed to the global community.
The analysis identifies three types of local image-making endeavours, which can help contribute to the understanding of the overall environmental imagery of the city. However, the first two are based on establishing real or imagined visual references borrowed from a real or imagined past. They delineate attempts to construct an architectural and urban identity through the selection of historic features stemming from Arabic heritage. The third type has produced manifestations that represent 'multiple modernities,' with the aim of satisfying perceived global aspirations and socio-economic transformations; these are effectively characterised by a desire for Doha to position itself as an aspiring global capital.

These results of examining print media corroborate the commitment toward image making: they unequivocally portray an image of Doha as an emerging international hub to the global community. The three categories examined that emphasise such a vision are business, culture and tourism, and real estate. On the one hand, business images represent Doha as an investment and transit hub. Images of business districts, bank headquarters, and industrial plants in the magazines are designed to promote businesses and encourage partnerships. The category of culture and tourism is tasked with creating an image of Doha as an international cultural hub with vast potential for attracting tourists to fascinating cultural facilities as well as exotic desert destinations. Images of new museum buildings, exciting cultural festivals, and rugged desert and seaside locales support such a vision. The third category is the real estate sector, which depicts attractive visiting, living, and working conditions for short-term visitors, investors, and a longterm talented workforce. However, while Qatar is busy promoting its capital city as an international knowledge and tourism hub through major capital investment in the architecture of educational and sport facilities, the text and images in the articles and advertisements examined do not convey such a vision due to their limited frequencies in the two magazines.

The analysis presented in this paper suggests that architecture in the city of Doha is produced in a manner that is in line with client aspirations through imaging. However, architectural debate is suffering from internal crisis that can be exemplified by the absence of critical consciousness that may contribute to the screening of ideas. In the city of Doha borrowed ideas are not, in many cases, screened or filtered as a result of the dearth of critical consciousness.

Critical consciousness represents feeling the urge to learn and criticise, and select and rationalise. Coupled with this consciousness is the 
appreciation that there is always an opportunity for changing or modifying the idea to sustain itself in the new setting. While there are varying degrees of success in some image making practices in Doha, many others do not involve critical consciousness; only image cloning. In essence, they are not the product of a screening apparatus generated by critical theories. Image making practices in Doha continue to subdue the profession to client aspirations through oversimplified imaging while ignoring the professional discourse that scrutinizes the quality of those images and the meanings they communicate to the public and the global community.

\section{ACKNOWLEDGEMENT}

This paper is developed as part of a comprehensive funded research project of the National Priorities Research Program, QNRF-Qatar National Research Fund (NPRP 09 - 1083 - 6 - 023).

\section{REFERENCES}

CASTELLS, E. 2004. The Relationship between Globalization and Cultural Identity in the Early $21^{\text {st }}$ Century. Barcelona Forum, Barcelona.

CORREA, C. 1983. Quest for Identity, in R. Powell (ed.), Architecture and Identity Concept Media/The Aga Khan Award for Architecture, Singapore.

FRAMPTON, K. 1985. Towards a Critical Regionalism: Six Points for an Architecture of Resistance, in $\mathrm{H}$. Foster (ed.), The Anti-Aesthetic. Bay Press, Seattle, WA.

HALL, S. 1990. Cultural Identity and Diaspora, in J. Rutherford (ed.), Identity: Community, Culture, Difference. Lawrence \& Wishart, London.

HARVEY, E. 1989. The Condition of Postmodernity. Blackwell, Oxford.

HASANIN, A. 2007. Urban Legibility and Shaping the Image of Doha: Visual Analysis of the Environmental Graphics of the 15th Asian Games, in Archnet-IJAR: International Journal of Architectural Research, 1(3), 37-53.

HUXTABLE, A. L. 1981. The Troubled State of Modern Architecture, in Architectural Record, 169 March, 72-79.

JENCKS, C. 2005. The Iconic Building: The Power of Enigma. Frances Lincoln, London.

LARICE, M. and MACDONALD, E. 2007 (eds.). The Urban
Design Reader. Routledge-Taylor and Francis Group, London and New York.

LYNCH, K. 1960. The Image of the City. MIT Press, Cambridge, MA.

MAHGOUB, Y. 2007. Architecture and the Expression of Cultural Identity in Kuwait, in The Journal of Architecture, 12 (2), 165-182.

OLE, B. 2005. Branding the Contemporary City - Urban Branding as Regional Growth Agenda, Plenary paper in the Proceedings of Regional Studies Association Conference Regional Growth Agendas, Aalborg.

SALAMA, A. M. 2005. Architectural Identity in the Middle East: Hidden Assumptions and Philosophical Perspectives, in D. Mazzoleni et al. (eds.), Shores of the Mediterranean: Architecture as Language of Peace Intra Moenia, Napoli, 77 85.

SALAMA, A. M. 2008. Doha: Between Making an Instant City and Skirmishing Globalization, in Middle East InstituteViewpoints, American University, Washington, DC., 40-44.

SALAMA, A. M. 2012. Architectural Identity Demystified: Visual Voices from the Arab World, in P. Emmons, J. Lomholt, and J. S. Hendrix (eds.), The Cultural Role of Architecture: Contemporary and Historical Perspectives. Routledge, London, 175-185.

SALAMA, A. M. and WIEDMANN, F. 2013. Demystifying Doha: On Architecture and Urbanism in an Emerging City. Ashgate Publishing Ltd., Surrey.

SALIYA, Y. 1986. Notes on the Architectural Identity in the Cultural Context, in MIMAR 19: Architecture in Development, Concept Media, Singapore, 32-33.

STILLERMAN, J. 1996. The Politics of Space and Culture, in Qualitative Sociology, 29, 507-530.

SYNNOTT, M. 2010. Towards an Ontological Understanding of City Branding, in 14 $4^{\text {th }}$ IRSPM: Challenges for Public Management, Berne.

TZONIS, A. and LEFAIVRE, L. 2003. Critical Regionalism: Architecture and Identity in a Globalized World. Prestel, New York, NY.

Author:

\section{Prof. Ashraf M. Salama}

Professor of Architecture and Urbanism Head, Department of Architecture and Urban Planning, Qatar University

Email:asalama@qu.edu.qa 